rev.relac.int.estrateg.segur.13(1):93-117,2018

\title{
Latin American integration as a wicked problem: the case for a plural approach*
}

\author{
Pablo Garcés Velástegui ${ }^{* *}$
}

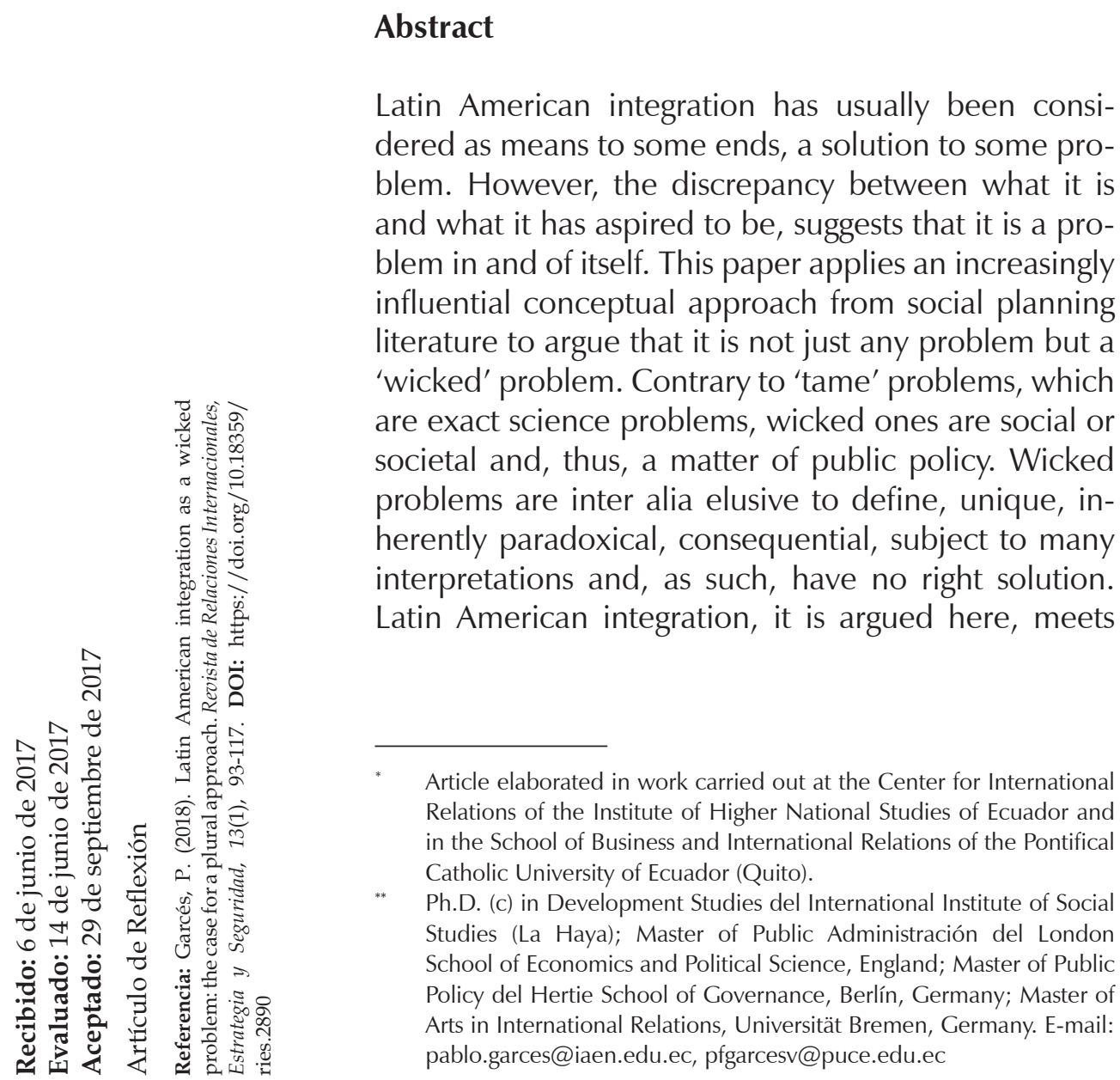


these criteria, and the implications are important for both academics and decision makers. Should regional integration continue to be approached as a tame problem, results are likely to continue to disagree with expectations.

Keywords: Latin America; regional integration; wicked problems; regionalism.

\section{Integración latinoamericana como un problema perverso: el caso para un abordaje plural}

\section{Resumen}

La integración latinoamericana ha sido considerada usualmente como un medio para un fin, una solución para algún problema. Sin embargo, la discrepancia entre lo que es y lo que ha aspirado a ser sugiere que es un problema en sí misma. Este papel aplica un enfoque conceptual de la literatura en planificación social con influencia creciente para argüir que no es uno cualquiera sino un problema "perverso". Contrario a los problemas 'dóciles', que son los problemas de las ciencias exactas, los perversos son sociales o de la sociedad y, por tanto, un tema de política pública. Los problemas perversos son inter alia difíciles de definir, únicos, inherentemente paradójicos, importantes, sujetos a muchas interpretaciones y, así, sin una solución correcta. La integración latinoamericana, se arguye aquí, tiene estas características y las implicaciones son relevantes para académicos y tomadores de decisión. Si la integración regional continúa siendo abordada como un problema dócil, los resultados probablemente seguirán discordando con las expectativas.

Palabras clave: América Latina; integración regional; problemas perversos; regionalismo.

\section{A integração latino-americana como um problema perverso: o caso para um abordagem plural}

\section{Resumo}

A integração latino-americana tem sido considerada como um meio para um fim, uma solução para algum problema. No entanto, a discrepância entre o que é e o que aspirava a ser sugere que é um problema em si. Este artigo aplica uma abordagem conceitual cada vez mais influente da literatura de planejamento social para argumentar que não é apenas qualquer problema, mas um problema "perverso". Em contraste com os problemas "dóceis", que são os problemas das 
ciências exatas, os perversos são sociais ou da sociedade, portanto, uma questão de política pública. Os problemas perversos são inter alia difíceis de definir, únicos, inerentemente paradoxais, importantes, sujeitas a muitas interpretações e, assim, sem solução. A integração latino-americana, argumenta-se aqui, tem estas características e as implicações são relevantes para acadêmicos e tomadores de decisões. Si a integração regional continua sendo abordada como um problema doce, os resultados continuarão discordando com as expectativas.

Palavras-chave: América Latina; integração regional; problemas perversos; regionalismo.

JEL codes: Economic Integration F15; International Relations, National Security, and International Political Economy: General F50; Trade: Other F19.

\section{Introduction ${ }^{1}$}

Latin American regional integration, throughout history, has been pursued as an answer to various questions. Different concerns and ideas about how to address these questions have dominated different moments, and the shape the integration of the region has taken illustrates the extent of their influence. Before and during the struggle for independence, early XIX century, the idea of a united Latin America, an idea of continentalism rather than nationalism (Vieira, 2005), was virtually synonymous with independence, at least for figures such as Ávarez, Monteagudo (Iño, 2013) and Bolívar (Tussie, 2009; Gil and Paikin, 2013). In the context of decolonization and the threat of recolonization by Spain, uni- ty was conceived as a promising strategy to guarantee territorial integrity and political independence (Briceño, 2012). As such, unification was the answer to security concerns. A number of efforts in South and Central America illustrate this intention (Dabène, 2009; Iño, 2013).

At the end of the century, the United States sought to advance an integration initiative in the whole continent, with a clear economic focus. The intention was to create a large customs union. By so doing Pan-Americanism would replace Hispano-Americanism (Dabène, 2009). This proposal, nonetheless, was received with skepticism, as a threat against economic independence in this case, and fueled Latin American solidarity anew. Regional integration

This paper has benefitted from the contributions of many colleagues. I am particularly indebted to Valeria Paredes for helpful discussions. I would also like to acknowledge the Instituto de Altos Estudios Nacionales of Ecuador as well as the Pontifical Catholic University of Ecuador for their support of this research. Any errors therein are my own. All the usual disclaimers apply. 
was considered, again, as an answer to this problem (Briceño, 2012), adding one component: anti-imperialism (Dabène, 2009).

During most of the XX century, integration was conceived as an answer to better deal with the Latin American's condition of the periphery in an increasingly globalized economy in which the terms of trade were not beneficial to its exports (Prebisch, 1986). The aim was to establish a common market, and it was furthered under the framework of import substitution industrialization, a protectionist approach (The Economic Commission for Latin America and the Caribbean [CEPAL, for its acronym in Spanish], 1959).

At the end of the century, once again, integration in the region gained momentum. Against the backdrop of the increasingly dominant orthodoxy of neoliberalism, integration was conceived as the answer to fix the region's economic performance by dint of (trade) liberalization. Consequently, efforts during this period came to be known as 'open' regionalism (Malamud and Gardini, 2012; Tussie, 2009). The results, however, were not as expected and, in fact; some mechanisms like The Andean Community (CAN, for its acronym in Spanish) and the Common Market of the South (Mercosur, for its acronym in Spanish) were considered to have fallen into a prolonged crisis due to this approach (Sanahuja, 2007).
Finally, in light of the poor results of neoliberalism, and in direct opposition to it, in the XXI century, regional integration gains impetus once more, this time under the banner of 'postliberal integration ${ }^{2}$. The latest effort is advanced as an alternative to the failures of previous attempts, especially the neoliberal one (Malamud and Gardini, 2012). In this sense, it is arguably the answer to the past and its almost exclusive focus on economic issues. In other words, while integration has been traditionally regarded as a means to economic ends, post-liberal integration seems to pursue multidimensional ends (inter alia political, social, environmental). The result of this process has been a plethora of coexisting and competing mechanisms with fuzzy delimitations (Tussie, 2009)

In this context, one question is bound to arise, namely, why has it proven to be so difficult for Latin American countries to integrate? The argument put forward here is that one plausible reason can be found in how the problem of integration itself has been understood. It seems that, thus far, the approach to this issue has been quite unidimensional (and hence unidisciplinary), virtually dominated by economic concerns. As great as the insights gained from this focus have been, this particular approach entails constraints as well, as other dimensions (and disciplines that study them) are arguably as important as the economic one. Thus, 
public and foreign policy inspired by this tradition carries its virtues but also its limitations.

Against this backdrop, an alternative approach seems warranted. Instead of considering it as a natural or exact science problem, the case is here made for Latin American regional integration to be conceived of as a 'wicked' problem. To do so, based on the seminal paper by Rittel and Webber (1973), originated in the social planning literature, the framework of wicked problems applied to Latin American integration, which consists of a decalogue that differentiates those problems from conventional or 'tame' problems. As is argued below, this means conceiving it as a societal problem, a matter of public policy. This entails recognizing the complexity and uniqueness of the problem, the plurality of legitimate ways to tackle it, and, the fallibility of knowledge regarding its definition and solutions. In so doing, the purpose of this paper is not to identify specific causes for the challenges that regional integration has faced and faces currently. Instead, it is to provide an alternative interpretation of the problem lest we persist with the same definitions of it and the same solutions, which can be part of the pro-blem themselves.

In that endeavor, I first set the stage with a brief review of Latin America's efforts to integrate as a region (or subregion) and argue why it is useful to regard its integration as a problem in and of itself, not only has a solution to a problem, as is a convention. Then, the case is made to regard Latin American integration as a specific kind of problem, a wicked problem by applying Rittel and Weber's (1973) approach. The final section concludes.

\section{Latin American Integration as a problem}

Latin America has experienced a number of efforts of regional integration. The intention has been to unite the countries making up the region. Much of the literature dates such experiences to mid-twentieth century. Some authors (Dabène, 2009; Iño, 2013) assert, however, that the very idea of Latina America as one political unit preceded the notion of independent states in the region. For them, the idea of Latin America as a whole was concomitant to the idea of independence in late XVIII and early XIX centuries. This suggests that after independence Latin America was in fact fragmented or balkanized and efforts ever since to form a larger political unit (above and beyond the member nations) could be conceived as a re-integration of sorts. Such approach can help explain the constant interest of the region on this undertaking, especially in light of its unsuccessful attempts.

Be that as it may, what is much clearer is that the history of Latin American integration shows many attempts to unite with significant variation in scope, motive, and depth. This is particularly true for the second half of the 
XX century, the period in which I shall focus. In this sense, there are at least three moments of (sub-) regional integration in Latin America. These are characterized by quantity (meaning an unusual number of integration initiatives at any given time), by quality (meaning a distinct approach to integration initiatives) or both.

In the first wave, Central America seems to have taken the initiative with an educational and eventually mainly economic focus. As early as 1948 the Central American Council for Higher Education was created (Csuca, for its acronym in Spanish). In 1951 the countries of this sub-region formed the Organization of Central American States (Odeca, for its acronym in Spanish ), and by 1960 they signed a multilateral treaty the objective of which was to pursue economic integration via the creation of the Common Market of Central America (MCCA, for its acronym in Spanish). Efforts in this direction were also carried out later on throughout the region. In 1960 the Latin American Free Trade Association (Alalc, for its acronym in Spanish) was established, in 1965 so was the Caribbean Free Trade Association (Carifta, for its acronym in Spanish) and by 1969 the Andean Pact followed suit. In 1973 Carifta became the Caribbean Community (Caricom), in 1975 the Latin American and Caribbean Economic System (SELA, for its acronym in Spanish) was established, and in 1980 the Alalc became the Latin American Integration Association (Aladi, for its acronym in Spanish).
The second moment can be placed at the end of last century. It was characterized by the dominance of a particular brand of economics: neoliberalism. In 1991 Mercosur was established and so was the Central American Integration System (SICA, for its acronym in Spanish). In 1994 the North American Free Trade Agreement (Nafta came into force, and the Free Trade Area of the Americas (FTAA) initiative was born (although it never took off). In the same year, the Association of Caribbean States (ACS) was established. Additionally, the Andean sub-region received new impetus in 1996 when it the Andean Pact became the CAN. This scenario paints a picture of a segmented and overlapping regionalism, described as a "messy outcome" (Malamud and Gardini, 2012, p. 116).

The third moment of integration in Latin America takes place at the start of the XXI century. The Bolivarian Alternative for the Americas (ALBA, for its acronym in Spanish) is founded in 2004, and so is the Community of South American Nations (CSN). The latter became the Union of South American Nations (Unasur, for its acronym in Spanish) in 2007. Four years later, in 2011, the Community of Latin American and Caribbean States (Celac, for its acronym in Spanish) was created. Finally, and during this same year another integration project with mainly an economic focus was born, the Pacific Alliance. For the first and second, at least, the interest has moved from economic issues to physical integration, political identities and secu- 
rity concerns (Malamud and Gardini, 2012). The latter, although includes other aspects (such as education), is dominated by a free market economic focus and, as such, appears rather as a response to the first ones.

The diversity of coexisting Latin American integration projects suggests a situation of sub-regionalism rather than regionalism per se. This has been described as a segmented and overlapping regionalism and has been argued that "[it] is not a manifestation of successful integration but, on the contrary, signals the exhaustion of its potential" (Malamud and Gardini, 2012, p. 117). This can be further exemplified when looking into some of the most successful projects. Given that success can be quite difficult to assess, perhaps it is best to conceive of it as survival $^{3}$, as it much less debatable to regard an extinct integration initiative as a failed one. This is particularly important in the case of Latin America. If the surviving projects show problems, it becomes clear that their success, measured with a higher bar (i.e. beyond mere survival) is rather doubtful. In order to illustrate this scenario, I shall review one existing mechanism in each sub-region, so as to cover the whole region:

Regarding the case of Central America: the MCCA. The Managua Treaty is the legal instrument that with which the Common Market of Central America is created. This document, signed in 1960, commits the parties to establish the common market no later than five years after the instrument has come into force (MCCA, 1960). However, this goal was not met in the time allocated for it, leading to reconsiderations about the process, its objectives and the strategies to achieve them.

About the case of the Caribbean: the Caricom. This mechanism was established with the goal of constituting a common market by 2008 (Sanahuja, 2007). This objective has not been met, and its future looks rather uncertain. Hence, it has also failed to fulfill its original aspirations (Malamud and Gardini, 2012)

Apropos the case of South America: the Mercosur. The constitutive document of the Mercosur, the Asunción Treaty, states that a common market should be constituted by December 31, 1994 (Mercosur, 1991). This goal was not met. In fact, according to Malamud (2011) this integration mechanism rather than a common market, it is an imperfect customs union (Sanahuja, 2007). Moreover, given recent events, he asserts that in the near future it is more likely to go back to a free trade zone than to move towards a common market.

As Axline (1981, p.176) pointed out more than three decades ago "[...] one of the most remarkable features of Latin American regional integration has been its capacity to survive and remain active and dynamic in the face of numerous obstacles, shortcomings, and failures." 
Concerning the case of the Andean sub-region: the CAN. This case is one of the oldest surviving integration mechanisms in the region. However, its original design had to undergo profound changes in the 1990s. Similarly, and perhaps most importantly, it has witnessed the exit of one-third of its members $^{4}$. In 1976 Chile decided to leave and in 2006 Venezuela denounced the Cartagena Treaty. Moreover, the customs union project failed after Peru and Colombia signed FTAs with the US.

Thus, it seems that Rosenthal's (1991) assessment a quarter of a century ago appears to be valid today as it was then. According to him, regardless of the objective, whether political, developmental o simply trade promotion, the initial aspirations of these mechanisms seemed overly ambitious, since many of them have failed to meet their objectives in the timetables established in their treaties. That is, they have not only not addressed the problems they sought to solve, but they have proven to be problematic themselves.

Hence, the discussion thus far has shown that although Latin American integration has been conceived as a solution to certain problems (e.g., security, economic growth, inequality, education, international insertion), it has proven to be a problem in itself.
This gains greater meaning when the concept problem is defined, as it is here, as the discordance between normativity and reality (Rittel and Webber, 1973). The evidence presented above points in that direction given the evident mismatch between "what ought to be" (what integration initiatives have been expected to be) and "what is" (what integration initiatives in fact are), i.e., the discrepancy between expectations and actuality. But problems can be of different sorts, and to contribute to addressing that of Latin American integration, it is warranted to ask what kind of problem it is? This question is the issue to which I now turn.

A caveat is necessary. In what follows, despite the notorious differences among the various mechanisms, the discussion refers to Latin American integration broadly conceived. It focuses on a characteristic shared by many, perhaps most, of them: the elusiveness of the consolidation of the processes (i.e., their problematic nature). This does not deny the uniqueness of each project (in fact it is a highlight in the argument below) but as a point of departure for present purposes, the difficulty that Latin American Integration has had to meet their original goals and aspirations (within the timetable as originally stated) as a common denominator is warranted.

Further, recently, the President of Ecuador has questioned the economic benefits that this integration project offers to this country and has stated the possibility of leaving it. 


\section{Latin American integration as a wicked problem}

To make sense of the problem of Latin American integration, I follow Rittel and Webber (1973) and apply their framework of "wicked problems" to the case at hand. The discussion can usefully begin with a differentiation between "social" and "natural" or "exact" problems. As I argue below, the former encompasses the issues concerning government and policy; the latter is mostly related to those with which natural and exact sciences are preoccupied.

Latin American integration is a "social" problem. Social in the scientific sense that it is a problem that involves people and the plurality of wills, motives, desires, and notions of "the good" they entail. That being so, it can also be considered a "societal" problem. In short, social or societal problems involve the different worldviews of stakeholders. As such, "[...] societal problems are matters of public policy" (Incropera, 2016, p. 14).

The importance of this distinction can be better grasped by contrasting it with "natural" or "exact" science problems. The latter, especially in disciplines like math or engineering, except for rare exceptions, can be solved in an agreed upon manner, if specialists in the field are given the relevant information (Rittel and Webber, 1973). That is, 1) the problem can be accurately defined; 2) the right solution can be found; and, as a corollary of the above, 3) both are mostly non-controversial. This character makes social problems inherently different from exact ones; it makes them 'wicked's.

Hence, the problems with which the natural or exact sciences are concerned can be considered "tame." This means that these problems, based on the right information and expertise, can be defined and are problems for which the right or correct solution is, in principle, findable. In other words, tame problems can be clearly identified as can be whether or not they are solved (Rittel and Webber, 1973). Conversely, wicked problems lack these characteristics and are prevalent in public policy issues (Head, 2008). As Rittel and Webber (1973, p. 160) assert, "[social, governmental and policy problems] are ill-defined; and they rely on an elusive political judgment for resolution (Not "solution". Social problems are never solved. At best they are only re-solved-over and over again)".

Following Rittel and Webber (1973, p. 160), these problems are called "[...] 'wicked' not because these properties are themselves ethically deplorable. We use the term 'wicked' in a meaning akin to that of 'malignant' (in contrast to 'benign') or 'vicious' (like a circle) or 'tricky' (like a leprechaun) or 'aggressive' (like a lion, in contrast to the docility of a lamb)." This ought to be complemented with Brown's (2010, p. 62) contribution when she states: "Wicked' here refers to issues that prove to be highly resistant to resolution through any of the currently existing modes of problem-solving." 
Beyond their social character, there are certain characteristics that wicked problems have that allow their identification. It is a decalogue proposed by Rittel and Webber (1973). To attest whether Latin American integration is, in fact, a wicked problem, it is necessary to analyze it against that framework. In light of the discussion above, the importance of this exercise is twofold: 1) defining the problem is a challenge in itself and therefore a valuable contribution; and, by so doing, 2) it can contribute to the generation of plausible solutions, since it can prove very detrimental to treat a wicked problem as a tame one, or viceversa.

\section{1) There is no definitive formulation of a wicked problem}

In the case of tame problems, an exhaustive and complete formulation can be provided. Such definition contains all the relevant information required for the problem-solver to find a solution for it (assuming, of course, they are expert in the field).

Wicked problems, on the other hand, are notoriously difficult to define and in fact, they elude conclusive definitions. This is because the information required to understand them depends upon the problem-solver's idea to solve them. According to Brown (2010), this is an underlying paradox (the source of the problem being the basis for its resolution), and wicked problems rest on such paradoxes. Moreover, she illustrates this by showing that the public service can be characterized by the coexistence of judgments of right and wrong, continuity and change, etc. Further, given than wicked problems are inherently societal problems, it is rather unlikely that consensus can be reached in pluralistic societies with competing (and conflicting) interests on the definition of a problem, let alone its solution (Incropera, 2016)

In the case of regional integration, a basic illustration shall suffice to make this point. Regional integration can be regarded as a multidimensional (i.e., multidisciplinary) issue, even if conventionally it has been mostly commercial (as in the case of the free trade zones and customs unions). This is because it involves political decisions that can have inter alia political (e.g., lost of sovereignty), social (e.g., labor conditions), environmental (e.g., regulations) motives as well as impacts. Therefore, the information required by a stakeholder to make sense of the problem is likely to differ depending on their background (professional or otherwise). A political scientist, a lawyer, and an economist will look at the problem differently given their distinct expertise for problem-solving. In other words, people's backgrounds provide them with specific tools for problemsolving; the upshot is that as useful as they can be in certain situations, they also run the risk of being considered all-purpose instruments, materializing the saying 'if all you have is a hammer, everything looks like a nail'.

What is the problem of Latin American integration? Quite a few plau- 
sible answers are depending on the approach. According to economic theory, perhaps the problem is the lack of sufficient scope and depth in transborder trade (Balassa, 1961b). After all, regional trade, between 2000 and 2004 , moved from $16 \%$ to $20 \%$ of the region's trade, and although this shows an upward trend, it is still relatively low (Sanahuja, 2007). If this is to be considered the problem, the solution will be to facilitate regional trade further. From a neofunctionalist perspective, it might be argued that it is the lack of supranational institutions (Haas, 1970). The literature has characterized Latin American integration projects as being intergovernmental in nature ${ }^{6}$ (Sanahuja, 2007), relying on inter-presidential dynamics (Malamud and Gardini, 2012). Should this be regarded as the problem, the solution would be to incentivize the transfer of sovereignty. A transactional analysis, in turn, may find it is the absence of a community with an identity (Deutsch, 1957) that curtails furthering the projects. In fact, it has been argued that it is an 'elitist' regionalism since it does not have the support of a wide part of the population and there is no common identity (Sanahuja, 2007). As can be gathered from the above, the solution, in this case, would be to strengthen the quantity and quality of communication channels directed towards the generation of a regional identity. Consequently, depending on the ideas (theories) favored by policy and decision makers as well as all other stakeholders, the problem will be defined in different ways according to what may be regarded as the solution.

Moreover, each of these interpretations may entail further causes. In the first case, how can trade be facilitated? If signing FTAs is the alternative, how can countries be motivated to engage in this process? Concerning the second, how can sovereignty be transferred? If creating institutions leading to the establishment of autonomous organisms is the solution, how can this be accomplished? Finally, in the third case, how can identity be generated? Improving regional communication can be an option to address this, but how can this be done? Hence, should the problem-solver formulate the problem regarding the causes for the discrepancy between what-is and what-ought-to-be, then they have also formulated the solution.

As such, articulating the problem of Latin American integration is itself the problem. And it can only be defined when a solution to it is also defined. This is because the process for the former is the same as the process for the latter. Rittel and Webber (1973, p. 161, emphasis in the original) argue that "[p]roblem understanding and

In fact, for one of Cepal's past general secretary, "The problem of Latin America is that the proper strategy to melt the different nationalisms into a single Latin American nationalism has not been found." (Dabène, 2009, p. 41) 
problem resolution are concomitant to each other" and that, in fact, "[t]he formulation of a wicked problem is the problem".

\section{2) Wicked problems have no stopping rule}

Because tame problems can be solved, the problem-solver knows when to stop. Clear criteria have been established to recognize when the solution for these problems has been found. Therefore, once the solution is found, the work is done.

That is not the case when it comes to wicked problems. Following from the previous point, since the processes for understanding a problem and (re)solving it are the same (because there are no criteria to determine sufficient understanding of a problem), and since the causal chains for a wicked problem have no end, then the problemsolver can always dig deeper, go further, do better. Thus, additional resources, (time, effort, etc.) can always improve the probabilities that a better understanding of the problem, and thereby a better solution, can be found. Consequently, the problemsolving exercise does not stop due to the intrinsic logic of the problem. It must stop for reasons like the scope of a project, resource limitation, etc.

The problem of Latin American integration has been tackled in different ways at different times, for reasons certainly beyond the nature of the problem. The examples described above showing the failure of many projects to meet their original objectives suggests deficiencies that can be due to a number of factors, such as: an underestimation of the scope of the goals, overestimation of the capacity of all parties to achieve them, rushed establishment of goals for whatever reason (where political ones often trump all others). In this sense, it could be argued that such failures are attributable to problems related to the design of the projects and, therefore, to their nature and their inherent logic. However, that position actually supports the argument elaborated here since it entails that should there have been more time or resources for a better design, the problem could have been solved. To be sure, the actual reasons are an empirical question. However, for this purpose of this essay suffice it to note that the evidence shows that one after the other, integration mechanisms has been unable to meet the aspirations set out by their members and in each case, those in charge could have been done better.

This brief review shows how the approaches have been singular in focus or one-dimensional and superficial along the causal chain. Perhaps the more telling evidence of this is the fact that, despite the modifications that some of the mechanisms have suffered, some integration projects face considerable difficulties, to the extent of being "in crisis," as in the case of CAN and Mercosur (Sanahuja, 2007). Therefore, analysis of the problem of Latin American integration does not 
stop due to reasons inherent in the logic of the problem but due to reasons external to it.

\section{3) Solutions to wicked problems are not true-or-false, but good or bad}

Once again, building on the last point above, given that there are criteria to determine when a tame problem has been solved, there are criteria to objectively determine when a proposed solution is correct or false. This is, of course, one of the virtues of the exact sciences, to which tame problems are associated.

The case of wicked problems is different. Various analysts, parties, stakeholders can all be equally prepared and entitled to assess the definition of a problem and therefore also its proposed solution. Although all can judge those proposals, none has the authority to establish formal norms to determine correctness. Thus, the evaluation can only be carried out in terms of good or bad instead of true or false.

Going back to the first point above, regional integration can be usefully considered as a multidimensional problem. As such, different experts (or stakeholders more broadly) from various disciplines may understand the problem differently and thus provide different legitimate solutions. However, no one set of criteria applies to all of them to assess truth or falsity. Moreover, this applies even if this multidimensionality is not conceded. Certain integration projects that are economic in nature, for instance seeking only to create only free trade zones, it may be argued that they are singular or onedimensional. Granting, for the sake of argument, the pertinence of such approaches, it still does not mean that consensus is likely to be found regarding problem definition and solution. Stakeholders with a background in the same field, with analogous expertise and the same information, may reach different conclusions. This is because even within the same discipline there can always be contending schools, theories, methods that can be used.

The goals of Latin American integration have evolved along with socioeconomic changes in the member countries, changes in the nature of the world economic situation, and changes in thinking about economic development. This evolution, considered in the context of different approaches to the study of integration, has created a situation in which some of the principal effects of integration (increases in trade, investment) may be interpreted as successes or as failures depending on the perspectives of the analysis (Axline, 1981).

Furthermore, regional integration in general and Latin American integration, in particular, is a political decision, not a technocratic one. This means that the interests, preferences, and expectations of all stakeholders, which in turn answer to such aspects as their beliefs, culture, and ideology, need to be factored in when defining the problem/finding the solution. This 
does not apply only to the diversity of member States of a given integration project, and the issue of intergovernmentalism (Sanahuja, 2007), but also to the many different interest group within States and their worldviews. Therefore, any solution that comes to the fore is best understood in terms of "good" or "bad," or perhaps even in terms of "better" or "worse".

\section{4) There is neither an immediate nor ultimate test of a solution to a wicked problem}

With tame problems, attempts towards their solution can be accurately evaluated within relatively short periods of time. Ideally, how good or bad an attempt to solve a problem can be determined on the spot. That is because 1) the solutions proposed have limited or constraint effects, which facilitate complete evaluation; and, 2) the tests to assess a proposed solution are entirely under the control of the people with the expertise and information.

Not so with wicked problems. When it comes to these problems, solutions have effects over a virtually limitless time and space. Any solution for a wicked problem can generate waves of consequences over an unbounded period, which may outweigh the benefits or advantages of the solution. Further, these consequences may affect a multiplicity of dimensions or spaces, many of which can turn out to be unexpected and undesired. Therefore, there can be no ultimate test to assess the solution.

This situation can be attested at the first rung of the economic integration ladder: the free trade agreement. FTAs have been considered as a means to an end, the latter being regional integration (Balassa, 1961a, 1961b). Thus, they can be regarded as a solution to the problem of integration. The logic of FTAs, in brief, consists on enlar ging markets to have access to greater demand, which incentivizes competition among producers and eventually improves productivity and competitiveness in supply via the possibility of reaching economies of scale. This eventually has benefits for consumers (lower prices and higher quality) and producers (higher revenues/ salaries and better quantity and quality of employment). Nevertheless, as the case of Nafta shows, this is a promise difficult to keep. Particularly in the case of employment, real wages and agriculture, this treaty has had unwanted impacts for Mexico (Polaski, 2006; Stiglitz, 2004). Moreover, not only can free trade agreements have undesirable economic repercussions but their effects can reach a wide array of issues. In the case of Nafta, such consequences have been identified in areas such as the environment (Davis and Kahn, 2010) and even human rights ${ }^{7}$ (Martínez, 1994).

For a wider discussion on the relationship between international trade and human rights see Abbott, Breining-Kaufmann and Cottier (2006). 
The illustrations above, indeed, present rather early assessments. The full effects of Nafta and all dimensions affected will remain to be a black box. Not even long-term analyzes can aspire to be exhaustive. Because of their nature, as has been argued, integration projects defy conclusive evaluations. "The full consequences cannot be appraised until the waves of repercussions have completely run out, and we have no way of tracing all the waves through all the affected lives ahead of time or within a limited time span" (Rittel and Webber, 1973, p. 163).

\section{5) Every solution to a wicked} problem is a "one-shot-operation"; because there is no opportunity to learn by trial-and-error, every attempt counts significantly

Exact science problems usually allow for various runs or attempts at solving a tame problem. That is, failed attempts rarely are prohibitive. In fact, those sciences are built on the experimental design (Moses and Knutsen, 2012), which means that trial and error is an essential part of their inner workings. Moreover, it is not evident that the outcome of such attempts, whether successful or not, has a fundamental impact on the course of societal affairs.

Conversely, every solution for wicked problems is always consequential. Their implementation leaves prints that cannot be undone. Solutions cannot be rehearsed (since they involve people and their lives, even applica- tions on samples instead of populations have effects on the lives of the people making up the sample) and once implemented they cannot be reversed. This is particularly evident in the case of public policy. Large public works (e.g., dams, canals), for all intents and purposes, are irreversible as well as long-lived, and so are public programs (e.g., school curricula, health services, cash transfers). In both cases, many people's lives would irreversibly be influenced by the solution adopted, not to mention the amounts or investment such projects would require, which is also irreversible.

On that account, any attempt to solve the problem of Latin American integration can prove irreversible in many senses. First, the costs required for this effort are irreversible. In the case of Unasur, countries contribute more than 50 million USD in total per annum (Noboa, 2016). The reason is twofold. On the one hand, there are the more evident direct costs in monetary terms. On the other, there is the opportunity cost, which, in the case of public policy, is the public policy that cannot be funded (Le Grand 2007).

Second, as already argued, FTAs can be considered as a popular solution and, as such, a useful illustration in this discussion. In basic terms, they seek to eliminate discriminatory barriers for products originated in the signing countries (Malamud, 2011), i.e., to liberalize the transborder circulation of goods and services. As such, they affect the terms of exchange in trade 
between countries. Depending on the terms agreed upon, this can be beneficial or detrimental to national production and people's lives. Should an unsatisfactory deal be struck, products from country A may be pushed out of its own market due to more competitive products from country B being imported. The consumption of some is the wage of others (Chang, 2014) and without a demand eventually, there is no supply. In time, ceteris paribus, this means unemployment for local industries. The Nafta, again, provides a case in point (Polaski, 2006).

Additionally, the same applies to more advanced forms of integration. For example, in the case of common markets, defined by the free mobility of factors of production, the circulation of labor can be consequential. Although none of the integration initiatives in the region has reached the common market phase, there has been increasing interest in facilitating the mobility of people across borders of member States in different mechanisms (Malamud, 2011). This, of course, has irreversible effects for migrants and their families.

These examples show that solutions for the Latin American integration problem can have irreversible effects and be longlived. Those characteristics mean that failed attempts become prohibitive and every trial counts lest countries have to incur in trying to reverse decisions and correcting for undesired effects, which can pose a different set of wicked problems.
6) Wicked problems do not have an enumerable (or an exhaustively describable) set of potential solutions, nor is there a welldescribed set of permissible operations that may be incorporated into the plan

The set of tools or resources that can be used to solve problems in the exact sciences is well defined. Mathematics is the prime example here since the set of operations available to solve its problems is explicit. Therefore, in the case of tame problems, it can be determined when all possible options to solve the problem have been identified and considered.

Wicked problems or policy problems present a different scenario. Possible solutions for them are, in principle, infinite. There is no exhaustive or comprehensive enumeration of all the alternatives that can be used to tackle them. There is always room for creativity and novelty in the generation of solutions.

In such fields of ill-defined problems and hence ill-definable solutions, the set of feasible plans of action relies on realistic judgment, the capability to appraise 'exotic' ideas and on the amount of trust and credibility between planner and clientele that will lead to the conclusion, 'OK let's try that'. (Rittel and Webber, 1973, p. 164)

The history of Latin American integration illustrates this quite well. There have been many attempts of different 
kinds and degree-seeking to answer the question how can Latin American countries integrate? Should it focus on trade (in a neoliberal manner) as in the case of the Pacific Alliance? Perhaps can it be a social aspect such as higher education, exemplified by Central American's experience with Csuca? Or should it be political as in ALBA? Or multidimensional as in Unasur? Is it possible to integrate the whole region under one project like Celac? Or are sub-regional arrangements like CAN, Mercosur, SICA more pertinent? Given the precedent of the region in this matter, it is not too far-fetched to assume that, should these initiatives fail; new alternatives will emerge.

\section{7) Every wicked problem is essentially unique}

As argued above, tame problems can be accurately defined. This entails that they can also be characterized. Despite the great variety of shapes and forms they can take, they can still be adequately known. Their features, similarities, and differences can be stated precisely. This facilitates classification within groups or families in such a way that they can be matched with the set of tools that is applicable for each of them.

The opposite is true for wicked problems since every one of them is essentially unique. By "essentially unique" it is meant that despite the number of properties that two or more problems may share, there always may be at least one distinguishing property that is of overriding importance. The problem-solver can never be certain that, between two cases, the differences do not outweigh the commonalities between them. This is so because of each problem belongs to its context, i.e., it is grounded in a particular time and place (Brown, 2010). Hence, classes, groups of families cannot be established for these problems. They cannot be pigeonholed. "For wicked problems, one solution does not fit all" (Incropera, 2016, p. 14).

It is not difficult to see how Latin American integration meets this criterion. By much the region's experience has been unsuccessful because it has failed to follow the European Union (EU) model (Dabène, 2009), purportedly the most advanced and successful regional integration project to date (Dieter, 2009; Kassim, 2007). Mechanisms aiming to constitute a common market such as the MCCA and the Mercosur exemplify this. However, as argued above, these very projects illustrate the difficulty in fulfilling the requirements of that model, since they are yet to do justice to their names.

Moreover, given the context dependence of wicked problems, calling Latin American integration unique can be misleading. In fact, each integration mechanism is unique. As such, this can be illustrated by moving from emulating practice (doing as the EU has done) to adopting theory (following a prescription). A close look at the foundational treaties of the cases studied here shows an effort to follow the EU but, by so doing, arguably also adopt the 
influence of Bela Balassa's (1961a, 1961b) phases to regional integration, namely, 1) free trade zone, 2) customs union, 3) common market, 4) economic union, 5) political union. However, each mechanism has experienced idiosyncratic difficulties at different levels, which makes their problems unique. For example, the CAN has lost a few members and faces the challenge of the bilateral trade agreements its members signed with external parties. The Alalc, in turn, had to undergo important changes in order to survive, such as renounce its commitment to FTAs and provide a more flexible scheme (challenging thereby Balassa), establish explicit support for relatively less developed states and go beyond trade to incorporate development goals. And other integration projects have their particular problems. What this suggests is that integration à la Balassa is not a one size fits all solution and believe it is akin to treating Latin American integration as a tame problem. That is, it has been diagnosed as a case belonging to the family of "integration" and given the treatment that apparently has worked in those cases. From this point of view, post-liberal integration efforts such as Celac or Unasur, with their multidimensional approach, can provide useful information in this discussion in the upcoming years.

\section{8) Every wicked problem can be considered to be a symptom of another problem}

Problems have been conceived of here as the discrepancies between what-is and what-ought-to-be. Once the pro- blem has been adequately defined, the process of finding a solution entails the scrutiny of the causal explanation for that discrepancy. Tame problems are relatively straightforward in this regard. In the exact sciences, addressing the cause of the problem is the solution.

In the case of wicked problems, it should be recalled; the problem is defined in terms of the solution. Thus, the very definition or formulation of the problem depends on what are considered to be its causes. Moreover, the causal chain can be, in principle, infinite. Therefore, addressing the solution poses a new wicked problem. In this sense, the original or first problem becomes a symptom of the new or second problem. To solve the second problem, once again, its causes have to be addressed, and this will become another wicked, "higher level," problem still, of which the second one was a symptom. Thus, the farther the causal analysis goes, the higher the level it reaches. To complicate matters further, there is no predetermined correct level at which wicked problems should be addressed. There is no such thing as a natural level nor can it be determined on logical grounds. This presents a conflict for the problemsolver. On the one hand, they should not address symptoms but problems. On the other, they should seek to reach the highest level possible but the higher the level in which the problem is formulated, the more general it becomes and the more difficult it is to take action. 
As was argued above, Latin American integration can be studied from different perspectives and depending on the framework adopted; different conclusions can be reached. For illustration, I shall only make a theoretical comparison using neofunctionalist theory (see Haas, 1970), arguably one of the most relevant for regional integration. From this point of view, one of the causes for the lack of consolidation of Latin American integration could be the absence of a transfer of sovereignty to the supranational level, since projects have established intergovernmental schemes solely. The cause of this, in turn, can be found in the insufficient cooperation (in kind and amount) on matters of mutual interest that can generate spill-over effects on others leading to the creation of institutions to address them. The causes of nationalism have further been discussed by different disciplines and depending on the preference of the problem-solver, the causal chain will reach ever higher levels along that path.

\section{9) The existence of a discrepancy} representing a wicked problem can be explained in numerous ways. The choice of explanation determines the nature of the problem's resolution

What I have thus far referred to as solving problems in the exact sciences, i.e., solving tame problems, is akin to the generation of knowledge under the positivist framework. The natural sciences are dominated by the pursuit of certainty to find the 'truth.' When the truth is found (i.e., the only correct answer), the tame problem is solved. The only accepted methodology that the problem-solver ought to follow in such ambitious undertaking is well established: positivism. I cannot dwell on the implications of this approach here I have done so elsewhere (see Garcés, 2016) and the literature offers insightful accounts (Caldwell, 1994). For this section suffice it to illustrate this methodology by its guiding compass, the hypothesis. To solve a problem, a hypothesis is tested. In basic terms, a hypothesis predicts a state of affairs, usuaIly a relationship between a couple of variables under certain conditions. If the relationship holds, i.e., the state of affairs is confirmed, the hypothesis is accepted, if not, it is rejected.

Hypotheses stated to solve a wicked problem have more than one way to be rejected or accepted. Depending on the theory, ideology or worldview used to approach the problem; the problemsolver will pay attention to different aspects of the problem. This becomes evident in the case of the professional practice: economists, sociologists, lawyers, anthropologists are likely to tackle the same wicked problem in quite different ways. One may argue that at least these disciplines have a minimum of scientific standards, established by their academic communities. Even this can be questioned, given the plurality of views existing within disciplines (Russell, 2010). But, for better or worse, wicked problems are not to be solved by technocrats (only). They are societal problems, which require political solutions. 
Accordingly, several non-scientific explanations may be used to accept or reject a hypothesis. As Rittel and Webber (1973) state:

\begin{abstract}
That is to say, the choice of explanation is arbitrary in the logical sense. In actuality, attitudinal criteria guide the choice. People choose those explanations which are most plausible to them. Somewhat but not much exaggerated, you might say that everybody picks that explanation of a discrepancy which fits his intentions best and which conforms to the action-prospects that are available to him. The analyst's 'worldview' is the strongest determining factor in explaining a discrepancy and, therefore, in resolving a wicked problem. (p. 166)
\end{abstract}

Motives guiding integration processes can be found in the documents by which these initiatives are generated. In this sense, it can be seen that the justification for integration in Latin America has been made in terms of "[...] to improve the living conditions of [member states'] peoples" (MCCA, 1960). "[...] to fulfill the hopes and aspirations of their peoples for full employment and improved standards of work and living" (Caricom, 1973). "[...] to achieve [certain ends] through the generation of integration and cooperation system seeking development that is economic, equilibrated, harmonic and shared among its members" (CAN, 1969, own translation). "[...] to accelerate [the member states'] processes of economic development with social justice" (Mercosur, 1991). Different projects have different motivations, but one that is present in most of them, one way or another, goes beyond measurable goals, namely, solidarity, fraternity, commonality (of history, culture, etc.). It is an empirical question to evaluate the importance of the latter. However, the constant presence of this element, and its emphasis on recent developments such as the ALBA and Unasur, certainly make it an extraordinarily (political and) relevant one.

\section{0) The problem solver has no right to be wrong}

Closely related to the above, solving tame problems is a matter of hypothesis testing. In the exact sciences, it is understood that hypothesis (alternative solutions to a problem) are there to be refuted. The more tests or refutations that the hypothesis can withstand, the better it's standing. That is how knowledge grows in positivistic terms (Caldwell, 1994) and, this case, it is how problem-solving techniques grow. Therefore, the problem-solver is not blamed for the rejected hypotheses, provided that they have followed the scientific rules. The trial-anderror approach mentioned above finds its corollary in this aspect.

\footnotetext{
8 For a review of positivism's approach to evaluate knowledge claims, as well as a plausible alternative for International Relations inquiry, see Garcés (2016).
} 
Wicked problems do not show this understanding. Due to the fact that they are societal problems, solutions seek to change some part of the world. In fact, wicked problems are generated by the society in which they are set and, thus, their resolution requires changes in that society (Brown, 2010). As such, they can be consequential in people's lives, and no tolerance is given to the problem-solver. They are liable for the solutions they implement and their repercussions, which, as argued above, are nearly infinite and impossible to fully assess. Moreover, this is further complicated by the plurality of worldviews that stakeholders may have. It would not be realistic to assume that consensus can be reached among all stakeholders regarding the definition of a wicked problem and its solution. What can be deemed acceptable for some may not be for others. Hence, it is likely that the problem-solver will always be at fault for their decision from some perspective. "We are thus led to conclude that the problems that [societal] planners must deal with are wicked and incorrigible ones, for they defy efforts to delineate their boundaries and to identify their causes, and thus to expose their problematic nature" (Rittel and Webber, 1973, p. 167).

Regional integration is a political decision with significant effects on people's lives that can extend over an undetermined period of time and can spread over a multiplicity of areas and dimensions. Because of this, the problem-solver (usually the head of state or government) has virtually no room for mistakes and should not expect to have full support for their decision. The same solution can have very different interpretations depending on the perspective. For example, how economic integration has been carried out has been interpreted quite differently, in opposing ways in fact, from different sectors. While FTAs have been adamantly promoted by right-wing politicians and policymakers in the region, they have been repudiated by those affiliated with the left. The opposite, left of center initiatives opposed by right-wing activists, has also been happened. In the history of Latin America, at different times, different camps have come out on top. In the second half of the XX century the region engaged in an effort to integrate under a protectionist framework: import substitution industrialization. Defenders of the free market condemned this initiative while its detractors supported it. More recently, whereas the Pacific Alliance can be considered as a victory for the free market, the FTAA, the last great effort to liberalize the whole continent, is its greatest lost. In both cases, the divergence between advocates and detractors was remarkable. Regardless of the outcome, the burden of the blame inevitably fell over the problem-solver.

\section{Conclusions}

Latin American integration has been conceived as a solution or an answer to address different problems and challenges. The many initiatives and the transformations that they have undergone 
show the constant interest in integration but also that this project is a problem in and of itself. What kind of problem? Adopting the definition of a problem as the discrepancy between what-is and what-ought-to-be, and following Rittel and Webber's (1973) seminal contribution to the social planning literature, this paper has argued that Latin American integration is a wicked problem.

Wicked problems are social or societal problems and, as such, a matter of public policy. As opposed to tame or exact science problems, wicked ones are inter alia elusive to define, unique, inherently paradoxical, and consequential, subject to many interpretations and, as such, have no right solution. Latin American integration appears to meet these criteria, and the implications are important. Whether for academics or practitioners, for all stakeholders, in fact, treating it as a tame problem, the most conventional and pervasive approach, is likely to (continue to) deliver poor results.

As well as different forms of governance and changes in ways of living, resolution of wicked problems requires a new approach to the conduct of research and to the decision-making based on that research. Rather than following the fixed trajectories of pre-existing research pathways, addressing wicked problems involves the inquirer and decision-maker in exploring the full range of investigative avenues. (Brown et al. 2010, p. 4)
The argument presented here is not in favor of exclusion but favor or inclusion. Singular or unidimensional approaches have provided great insights about the social world in general and Latin American integration in particular. However, in light of the rich diversity of worldviews produced by different perspectives on the same matter, paying attention to only one of them to define and solve a problem can be problematic as each might hold only one piece of the puzzle. Consequently, in light of argument above, this is rather an invitation to welcome, with healthy criticism, different approaches, disciplines, ideologies, and perspectives, to the definition and (re)solution of the problem of Latin American integration. That is, this is a call for plurality.

This has implication for both academia and practice. In academia, the literature shows that integration of the region is mostly studied from a unidisciplinary orientation. This is perhaps to be expected since policy and decision makers are influenced by academic research. Thus, this would entail a call to engage in more inter- multi- and transdisciplinary research. In practice, given that this is a societal problem, it is all the more important to listen attentively to all stakeholders. If all continue to talk past each other, the problem of and the solution to Latin American integration is likely to remain the proverbial elephant and those concerned with it, the proverbial blind men. 


\section{References}

Abbott, F., Breining-Kaufmann, C. and Cottier, T. (Eds.) (2006). International Trade and Human Rights: Foundations and Conceptual Issues. Michigan: The University of Michigan Press.

Andean Community of Nations (CAN). (1969). Andean Subregional Integration Agreement, Cartagena Agreement. Retrieved April 25, 2016, from http://www.wipo. int/wipolex/es/regeco treaties/ details.jsp?group id $=24 \&$ treaty $\underline{\mathrm{id}=393}$

Axline, A. (1981). Latin American Integration: Alternative Perspectives on a Changing Reality. Latin American Research Review, 16(1), 167-186.

Balassa, B. (1961a). The Theory of EConomic Integration. Abingdon: Routledge.

Balassa, B. (1961b). Towards a Theory of Economic Integration. Kyklos International Review for Social Sciences, 14(1), 1-17.

Briceño, J. (2012). Autonomía y desarrollo en el pensamiento integracionista latinoamericano. In J. Briceño, A. Rivarola and A. Casa. Integración Latinoamericana y Caribeña: Política y Economía (pp. 27-54). Madrid: Fondo de Cultura Económica.

Brown, V., Deane, P., Harris, J. and Russell, J. (2010). Towards a Just and Sustainable Future. In V. Brown, J. Harris and J. Russell (Eds.), Tackling Wicked Problems (pp. 3-15). London: Earthscan.
Brown, V. (2010). Collective Inquiry and its wicked problems. In V. Brown, J. Harris and J. Russell (Eds.). Tackling Wicked Problems (pp. 6181). London: Earthscan.

Caldwell, B. (1994). Beyond Positivism. Economic Methodology in the Twentieth Century. New York: Routledge.

Caribbean Community (Caricom). (1973). Treaty Establishing the Caribbean Community, Treaty of Chaguaramas. Retrieved April 25, 2016, from http://www.wipo.int/ wipolex/es/regeco treaties/details. jsp?group_id=24\&treaty_id=316

Central American Common Market (MCCA) (1960). General Treaty 1 On Central American Economic Integration Between Guatemala, El Salvador, Honduras and Nicaragua. Retrieved April 25, 2016 from http://www.wipo.int/wipolex/es/ regeco treaties/details.jsp?group $\mathrm{id}=24 \&$ treaty $\mathrm{id}=390$

Chang, H-J. (2014). Economics: The User's Guide. New York: Bloomsbury Press.

Dabène, O. (2009). The Politics of Regional Integration in Latin America: theoretical and comparative exploration. New York: Palgrave Macmillan.

Davis, L. and Kahn, M. (2010). International trade in used vehicles: The Environmental Consequences of Nafta. American Economic Journal: Economic Policy, 2(4), 58-82.

Deutsch, K. (1957). Political community and the North Atlantic Area. 
Princeton: Princeton University Press.

Dieter, H. (2009). Europe's Crisis Management: Missed Opportunities. The Journal of Australian Political Economy, (64), 141-156.

Gil, L. and Paikin, D. (2013). Mapa de la Integración Regional en América Latina: procesos e instituciones, Nueva Sociedad, 1-33.

Garcés, P. (2016). Neither 'mind' nor 'things' but acting: some philosophical implications of Pragmatism for International Relations inquiry. Analecta Política, 6(11), 263-284.

Haas, E. (1970). The Study of Regional Integration: Reflections on the Joy and Anguish of Pretheorizing. International Organization, 24(4), 607-646.

Head, B. (2008). Wicked Problems in Public Policy. Public Policy, 3(2), 101-118.

Incropera, F. (2016). Climate Change: a wicked problem. New York: Cambridge University Press.

Iño, W. (2013). Ideas y proyectos de integración Americana a finales del siglo XVIII y en el siglo XIX: Miranda, Álvarez, Monteagudo, Bolívar, Martí y Hostos. Documento de Trabajo. Consejo Latino Americano de Ciencias Sociales (Clacso).

Kassim, H. (2007). The Institutions of the European Union. In C. Hay and A. Menon (_Eds.). European Politics (pp. 168-199). New York: Oxford University Press.
Le Grand, J. (2007). The Other Invisible Hand, delivering public services through choice and competition. Princeton: Princeton University Press.

Malamud, A. (2011). Conceptos, teorías y debates sobre la integración regional. Norteamericana. Revista Académica del CISAN-UNAM, 6(2), 219-249.

Malamud, A. and Gardini, G. (2012). Has Regionalism Peaked? The Latin American Quagmire and its Lessons. The International Spectator, 47(1), 116-133

Martínez, R. (1994). Nafta's Effect on Human Rights at the Border. University of California Davis Law Review, (27), 979-985.

Moses, J. and Knutsen, T. (2012). Ways of knowing: competing methodologies in social and political research. Second Edition. London, UK: Palgrave

Noboa, A. (2016). Ecuador es el principal financista de la Unasur desde su creación. El Comercio, August 30. Available at http://www.elcomercio.com/actualidad/ecuador-financista-unasur-ernestosamper-dinero. html

Polaski, S. (2006). The Employment Consequences of NAFTA. Testimony Submitted to the Senate Subcommittee on International Trade of the Committee on Finance

Prebisch, R. (1986). El Desarrollo Económico de la América Latina y Algunos de sus Principales Proble- 
mas, Desarrollo Económico, 103, 479-502

Rittel, H. and Weber, M. (1973). Dilemmas in a general theory of planning. Policy Sciences, 4(2), 155-169.

Rosenthal, G. (1991). Un Informe Crítico a 30 años de Integración en América Latina, Nueva Sociedad 113, 60-65.

Russell, J. (2010). A Philosophical framework for an open and critical transdisciplinary inquiry. In $\mathrm{V}$. Brown, J. Harris and J. Russell (Eds.). Tackling Wicked Problems (pp. 3160). London, UK: Earthscan

Sanahuja, J. (2013). La Unión Europea y el regionalismo latinoamericano: un balance. Investigación \& Desarrollo, 21(1), 156-184.

Sanahuja, J. (2007). Regionalismo and Integración in América Latina: balance y perspectivas. Pensamiento Iberoamericano, 0, 75-106.

Southern Common Market (Mercosur) (1991). Treaty Establishing a Common Market between the Argentine Republic, the Federal Republic of
Brazil, the Republic of Paraguay and the Eastern Republic of Uruguay, Treaty of Asunción. Retrieved April 25 2016, from http://www.wipo.int/ wipolex/es/regeco treaties/details. jsp?group id =24\&treaty id $=436$

Stiglitz, J. (2004). The Broken promise of NAFTA. The New York Times. Available at http://www.nytimes. com/2004/01/06/opinion/thebroken-promise-of-nafta.html? $\underline{r=0}$

The Economic Commission for Latin America and the Caribbean (CEPAL) (1959). Significación del mercado común en el desarrollo económico de América Latina. In Naciones Unidas (Ed.), El mercado común latinoamericano (pp. 3-10). New York: United Nations

Tussie, D. (2009). Latin America: Contrasting Motivations for Regional Projects. Review of International Studies, 35, 169-188

Vieira, E. (2005). Orígenes de las dificultades de la integración de América Latina. Agenda Internacional, 11(22), 185-209. 